\title{
Gambaran Klinis Osteomielitis Kronik pada Ewing Sarcoma : Laporan kasus
}

\author{
Sri Mulatsih, Vicka Farahdiba \\ Bagian Ilmu Kedehatan Anak Fakultas kedokteran UGM/RSUP Dr. Sardjito, Yogyakarta
}

\begin{abstract}
Ewing sarcoma merupakan tumor tulang pada anak yang sering dijumpai. Gambaran klinis maupun radiologis tumor ini sangat mirip dengan infeksi tulang yaitu osteomielitis akut maupun kronik, dengan keluhan benjolan pada tulang yang dirasa nyeri. Dengan demikian, sering kali pasien datang terlambat karena di diagnosis infeksi tulang. Diperlukan pemeriksaan patologi anatomi pada pasien dengan osteomielitis kronis untuk menyingkirkan adanya keganasan tulang. (Sari Pediatri 2009;11(1):52-5).
\end{abstract}

Kata kunci: tulang, nyeri, benjolan, sarkoma, ostomielistis

$E$ wing sarcoma adalah tumor tulang terbanyak kedua dan paling mematikan pada anak. Angka kejadian di Amerika Serikat adalah sekitar 2,1: 1 juta anak dengan penyebab yang belum diketahui. ${ }^{1}$ Paling sering tumor ditemukan sebagai lesi monostatik pada bagian metafisis dan diafisis dari tulang panjang ekstremitas. Tumor juga dapat muncul meskipun jarang pada pelvis, iga, dan skapula. $^{2}$

Gambaran klinis sering mirip dengan osteomielitis akut atau kronik, seperti dijumpai adanya gambaran klinis demam berulang, anemia ringan, leukositosis, peningkatan LED, dan LDH. ${ }^{2,3}$ Pasien juga sering datang dengan keluhan benjolan yang tumbuh dengan

\section{Alamat korespondensi}

Dr. Sri Mulatsih, Sp.A(K), Bagian Ilmu Kesehatan Anak, RSUP Dr. Sardjito/ FK UGM. Jl. Kesehatan No.1, Sekip utara, Yogyakarta. Tel: (0274) 553142, Fax: (0274) 583745, E-mail: smulat@gmial.com cepat dalam waktu beberapa minggu atau bulan disertai dengan nyeri. ${ }^{2}$ Diagnosis osteomielitis ditegakkan apabila memenuhi dua dari kriteria nanah aspirasi tulang, kultur positif pada darah atau tulang, terdapat tanda-tanda inflamasi dan gambaran radiologis atau scan tulang yang mendukung. Pemeriksaan khusus untuk Ewing sarcoma belum ada sehingga gambaran patologi anatomi masih merupakan gold standard. ${ }^{1}$

\section{Laporan Kasus}

Seorang anak perempuan 5 tahun datang dengan keluhan benjolan pada sendi kaki kanan yang disertai dengan nyeri, demam, dan kaki tidak dapat digerakkan. Keluhan muncul sejak sembilan bulan yang lalu. Anak pertama kali dibawa ke RS HI dan dilakukan pemeriksaan rontgen dada, tulang vertebra, dan sendi. Dari hasil pemeriksaan tersebut disimpulkan anak menderita tuberkulosis (TB) paru dan mendapat pengobatan tuberkulosis. 
Empat bulan setelah pengobatan tuberkulosis, keluhan masih ada sehingga anak dibawa ke RS Sardjito Yogyakarta. Di RS Sardjito dilakukan pemeriksaan aspirasi dari cairan sendi namun tidak ditemukan infeksi bakteri atau bakteri tahan asam, serta tidak ditemukannya sel ganas. Berdasarkan hasil tersebut maka anak didiagnosis sebagai JIA (juvenile idiopathic arthritis) dan mendapatkan terapi ibuprofen serta meneruskan pengobatan tuberkulosis. Setelah menyelesaikan pengobatan tuberkulosis dan pengobatan JIA dua bulan, keluhan bengkak dan nyeri pada sendi masih menetap sehingga anak datang kembali ke RS Sardjito.

Dari pemeriksaan klinis, kami jumpai anak dengan status gizi kurang, pembengkakan pada sendi kaki kanan yang secara palpasi disertai panas, kemerahan, nyeri, dan keterbatasan gerak (Gambar 1). Skor $\mathrm{TB}=3$ dan dijumpai limfadenopati, masa abdomen, paraparesis inferior flaksid, dan retensi urin tanpa adanya pembesaran hepar atau lien tetapi tidak

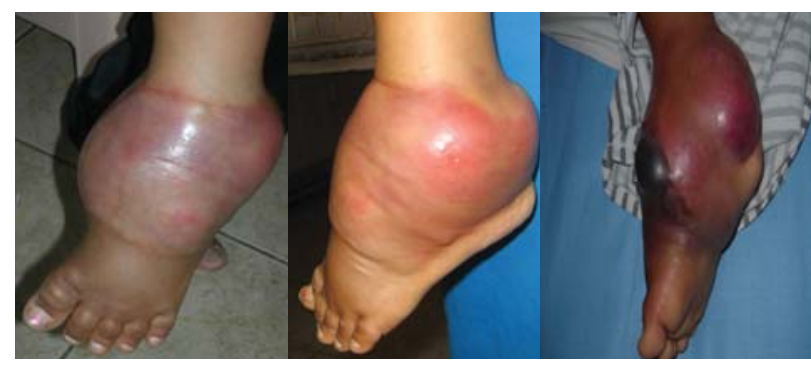

Gambar 1. Sendi kaki kanan: terdapat pembengkakan sendi progresif dalam waktu sebulan

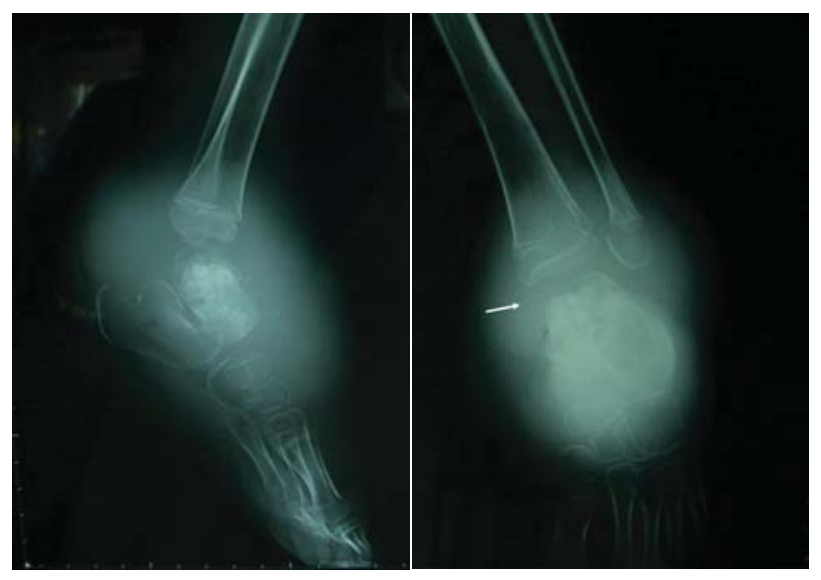

Gambar 2. Gambaran radiologis sendi kaki kanan: terdapat pelebaran sendi kaki dan penebalan jaringan lunak. ditemukan uveitis pada mata.

Pemeriksaan laboratorium menunjukkan anemia hipokrom mikrositer dan leukositosis dari Gambaran apusan darah tepi menunjukkan anemia hipokrom mikrositer dengan gambaran infeksi. Gambaran radiologis didapatkan pelebaran sendi dan penebalan jaringan lunak yang menunjukkan proses infeksi kronis, mengarah kepada osteomielitis TB (Gambar 2).

Gambaran radiologis dada dijumpai perbaikan TB paru (Gambar 3), tulang vertebra dijumpai kompresi pada vertebral torakal 11 dan abses paravertebral pada vertebral torakal 9-12 (Gambar 4).

Hasil gambaran patologi anatomi apirasi cairan sendi kaki dijumpai sel malignansi yang mengarah pada Ewing sarcoma (Gambar 5).

Dari gambaran aspirasi sumsum tulang dijumpai sel metastase (Gambar 6).

Dari hasil CT scan abdomen dijumpai urinoma akibat adanya retensio urin kronik pada anak (Gambar 7).

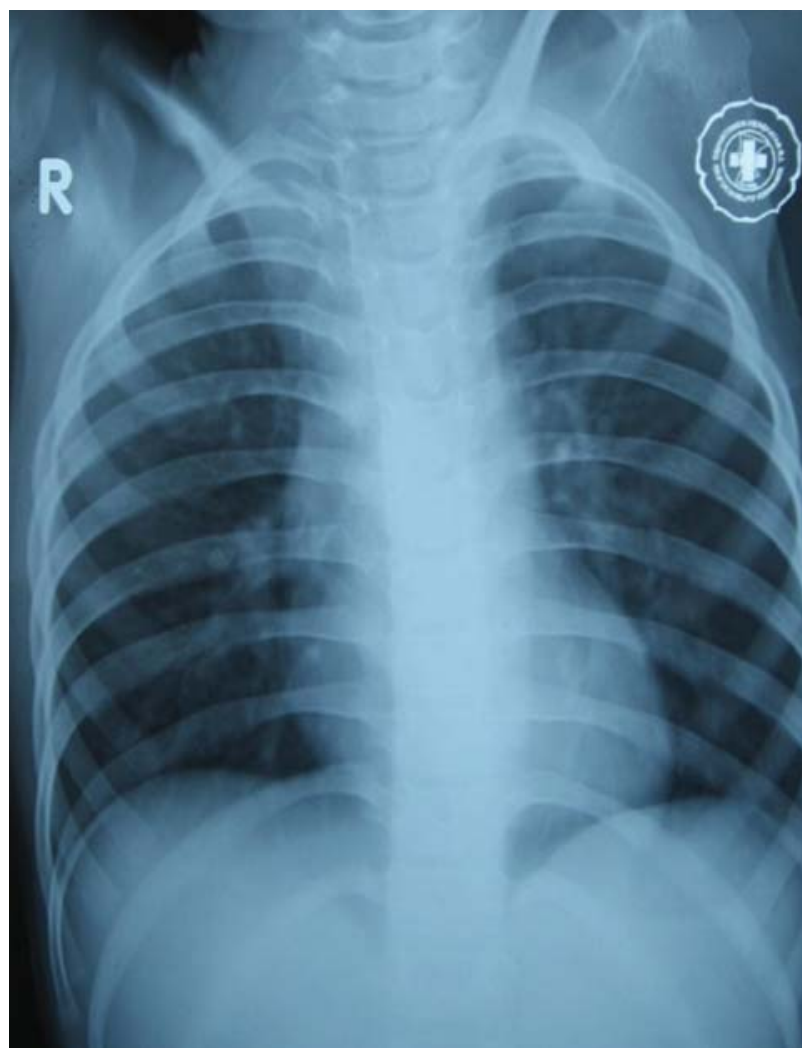

Gambar 3. Gambaran radiologis dada: terdapat perbaikan dari TB paru 


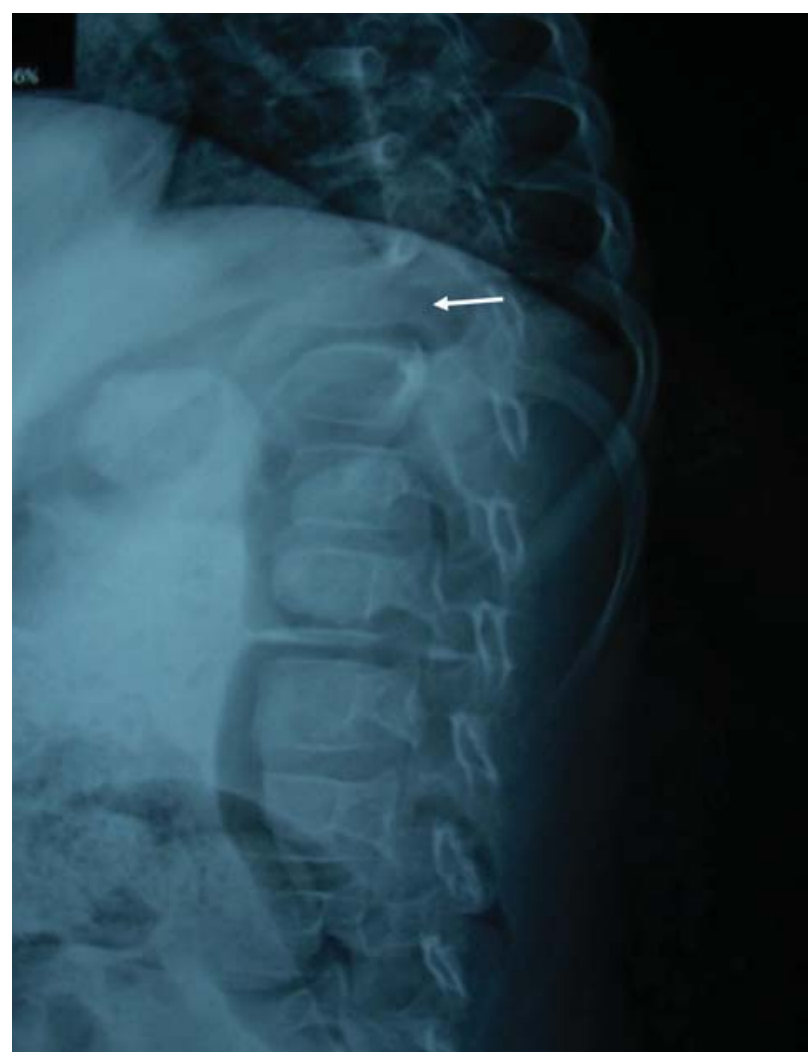

Gambar 4. Gambaran radiologis vertebra: ditemukan kompresi pada V. th 11 dan paravertebral absess pada $V$ th $9-12$

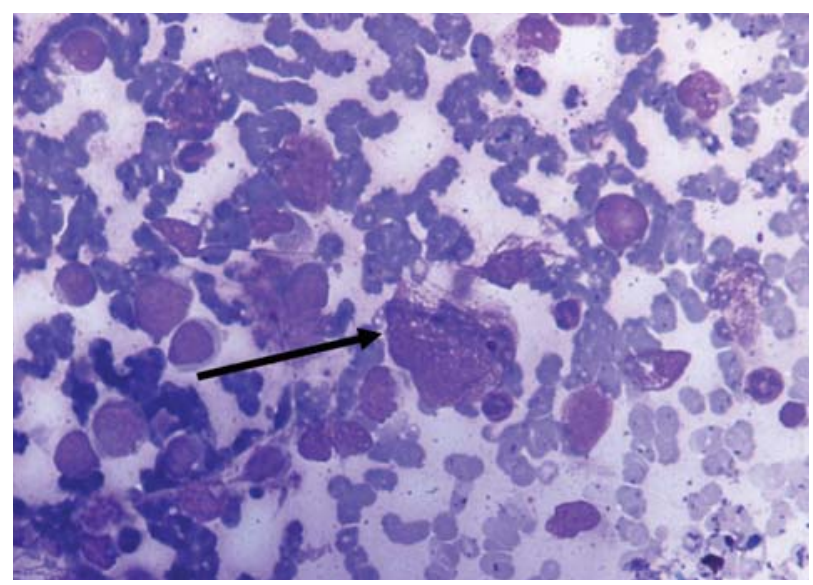

Gambar 5. Gambar patologi anatomi: tampak sel malignansimesenkimal

Berdasarkan hasil patologi anatomi di tegakkan diagnosis Ewing sarcoma dan direncanakan menjalani kemoterapi.

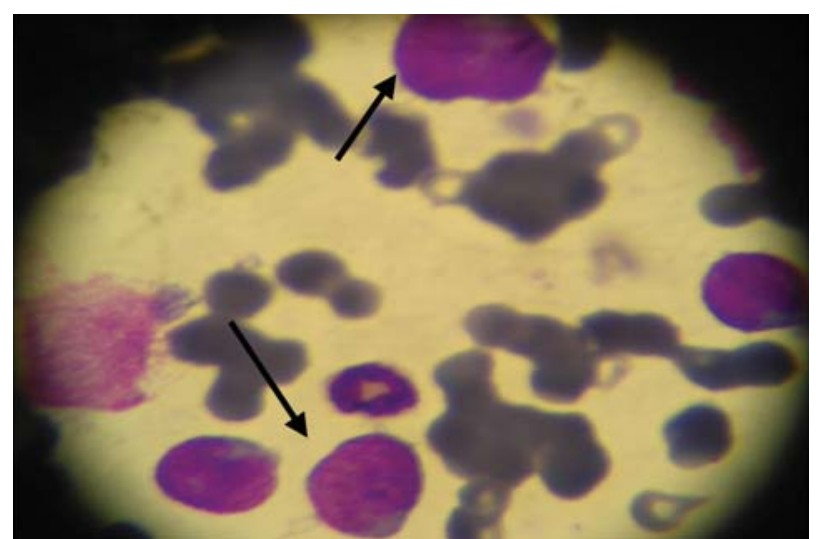

Gambar 6. Gambaran aspirasi sumsum tulang : dijumpai sel metastase

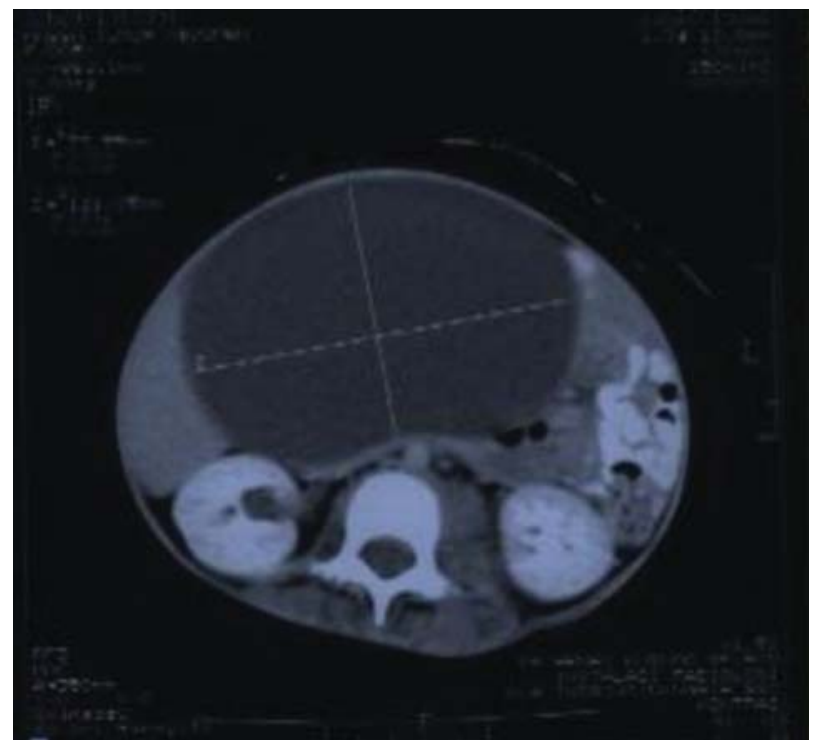

Gambar 7. Gambaran CT abdomen : terdapat urinoma

\section{Diskusi}

Gejala klinis awal dari osteomielitis adalah pembengkakan jaringan lunak dan keterbatasan gerak. ${ }^{4}$ Pada Ewing sarcoma gejala klinis utama juga ditemukannya nyeri, bengkak pada tulang atau sendi dan sering muncul masa yang tumbuh progresif disertai nyeri. ${ }^{2}$ Gejala sistemik seperti penurunan berat badan dan demam juga sering mengarah kesalahan diagnosis kepada osteomielitis kronik seperti dijumpai pada kasus ini. Diagnosis nyeri tulang yang terlokalisir pada anak meliputi osteomielitis, artritis septik, reumatoid artritis akut, demam rematik akut dan malignansi 
(leukemia, Ewing sarcoma, metastase neuroblastoma), infark tulang (penyakit sickle cell) dan toxic synovitis. Dianjurkan pada setiap anak dengan pembengkakan tulang dan demam tetap dipikirkan menderita osteomielitis akut sampai diagnosis tersebut dapat disingkirkan. ${ }^{3,4}$

Diagnosis dari osteomielitis akut dapat ditegakkan bila ditemukan dua dari kriteria berikut, ditemukannya pus dari dari aspirasi tulang, kultur positif dari darah atau tulang, terdapat tanda inflamasi, gambaran radiologis atau scan tulang yang mendukung. Sekitar dua minggu dapat dijumpai perubahan anatomis tulang yang dapat terlihat secara radiologis konvensional. ${ }^{3.4}$ Isolasi patogen dari kultur darah, tulang atau pus subperiosteal membuktikan secara pasti diagnosis osteomielitis. Dilaporkan hasil kultur darah positif $50 \%-60 \%$ dan kultur aspirasi tulang positif $70 \%-80 \%$ dari beberapa kasus. Kultur dari aspirasi tulang perlu dilakukan terutama bila pasien sudah mendapat terapi antibiotik sebelumnya karena hasil kultur dari aspirasi tulang masih dapat positif terutama apabila kuman patogen adalah $S$. aureus. ${ }^{3}$

Belum ada pemeriksaan khusus untuk mendiagnosis Ewing sarcoma. ${ }^{1}$ Tumor pada umumnya berasal dari batang tulang panjang, secara radiologis dapat dijumpai penebalan periosteum yang sering mirip dengan gambaran osteomielitis. ${ }^{5}$ Ewing sarcoma bersifat progresif dan destruktif yang dapat melibatkan seluruh tulang panjang. Terdapat destruksi litik dan kadang disertai gambaran pembentukan tulang baru. ${ }^{5,6}$ Ketika tumor meluas sampai ke korteks tulang akan terdapat gambaran peningkatan dari periosteum tulang yang disertai pembentukan tulang baru. Gambaran reaksi subperiosteal yaitu gambaran lapisan pembentukan tulang baru yang menyerupai gambaran lapisan kulit bawang sering dijumpai ${ }^{5,7}$ Pengambilan sampel yang tepat dari tumor perlu dilakukan untuk pemeriksaan patologi anatomi. $^{2}$

Pada kasus kami, pada pemeriksaan radiologis sendi kaki kanan didapat gambaran pelebaran sendi dan penebalan jaringan lunak yang menunjukkan adanya suatu proses infeksi kronik seperti pada osteomielitis TB tetapi yang tidak responsif pada pengobatan TB. Gambaran histopatologi anatomi cairan sendi berupa sel mesenkimal malignansi mengarah pada Ewing sarcoma.

Dua puluh persen sampai dengan dua puluh lima persen Ewing sarcoma dapat bermetastasis, ke paru dan sekitarnya $50 \%$, tulang $25 \%$, sumsum tulang. Diperlukan pemeriksaan aspirasi sumsum tulang pada pasien Ewing sarcoma, ${ }^{2}$ seperti pada pasien yang kami laporkan. Maka perlu difikirkan suatu keganasan tulang pada pasien yang menderita pembengkakan tulang kronik disertai nyeri sampai terbukti sebaliknya sehingga penanganan Ewing sarcoma yang mematikan tidak terlambat. Disimpulkan bahwa gambaran klinis dan radiologis Ewing sarcoma dapat menyerupai osteomielitis kronik, pemeriksaan histopatologi secara dini perlu dilakukan pada kasus osteomielitis kronik untuk menyingkirkan suatu keganasan tulang.

\section{Daftar pustaka}

1. AS Carola, Arndt, M William Crist. Common musculoskeletal tumors of childhood and adolescence. N Engl J Med 1999;30:342-50.

2. Strauss G, Ludwig MD. Ewing sarcoma. 2007. Didapat dari: http//www.emedicine.com/topic275. Html.

3. Gold Ronald. Diagnosis of osteomyelitis. Pediatr Rev1999;12:292-6.

4. Roy R Dennis. Osteomyelitis. Pediatr Rev1995; 16: 380-4.

5. J Norman. Osteosarcoma. Pediatric Review 1991;12: 333-43.

6. Horowitz M E, Tsokos MG, DeLaney TF. Ewing's sarcoma. CA Cancer J Clin 1992;42:300-20.

7. Hevroni Avigdor, Koplewitz Z Benjamin. Bone within Bone-Chronic Osteomyelitis. N Engl J Med 2007; 356;8:e7. 